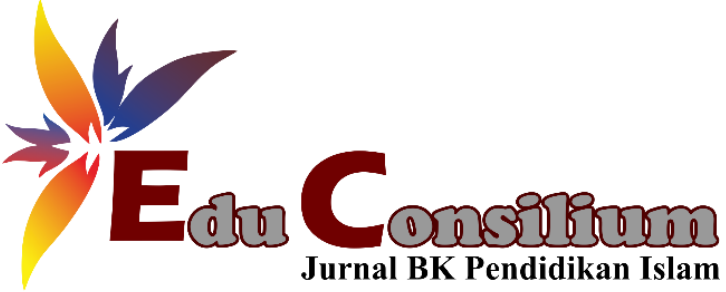

\title{
PENGEMBANGAN KERJASAMA PROFESIONAL PROGRAM BIMBINGAN DAN KONSELING
}

\author{
Rusmiyati $^{1}$, Arina Mufrihah ${ }^{2 *}$, Nur Erlinasari ${ }^{3}$ \\ ${ }^{1}$ Program Studi Bimbingan dan Konseling, STKIP PGRI Sumenep, Jalan Trunojoyo, Gedungan, Sumenep, Jawa \\ Timur, 69451, Indonesia \\ ${ }^{2}$ Bimbingan dan Konseling Pendidikan Islam, Institut Agama Islam Negeri Madura, Jalan Panglegur KM 04, \\ Pamekasan, Timur, 69371, Indonesia \\ ${ }^{3}$ Guru Bimbingan dan Konseling, SMA Muhammadiyah 1 Yogyakarta, Jalan Gotongroyong I, Karangwaru, \\ Kec. Tegalrejo, Kota Yogyakarta, Daerah Istimewa Yogyakarta 55241, Indonesia \\ *e-mail:arinamufrihah@iainmadura.ac.id.
}

\begin{tabular}{ll}
\hline \hline & Abstract \\
\hline Keywords: & Aims of this descriptive qualitative research are organizing cooperational models of \\
Individual & guidance and counseling and analizing use of those professional cooperation \\
planning; & activities between counselor and other professionals for students as targeting subject \\
Professional & of guidance and counseling service. Author got the needed data from observation \\
cooperation; & method, interview method, and documentation method, while subject of this research \\
Students' & are guidance and counseling teachers and students. Guidance and counseling \\
potential; & teachers have created some cooperational patterns with motivator, psychology \\
School system & institution, college, and alumna. By these cooperational programs, students \\
support. & acknowledged that they got many supports in understanding and developing their \\
& potentials, coping their obstacles, and programming their individual planning.
\end{tabular}

\begin{tabular}{ll}
\hline \hline & Abstrak: \\
\hline Kata Kunci: & Penelitian ini merupakan penelitian deskriptif kualitatif dengan tujuan \\
Kerjasama & mengorganisasikan pola-pola kerjasama bimbingan dan konseling dan menelaah \\
profesional; & manfaat yang diperoleh siswa sebagai subjek sasaran layanan BK dari kegiatan \\
Dukungan sistem; & kerjasama profesional antara konselor dengan pihak-pihak profesional lainnya. Data \\
Perencanaan & penulis peroleh dari observasi, wawancara, dan dokumentasi, subjek dalam \\
individual; & penelitian ini adalah Guru BK dan siswa. Penulis memperoleh hasil penelitian \\
Potensi siswa. & berupa pola kerjasama yang dijalin oleh guru BK ialah dengan: (1) motivator; (2) \\
& lembaga psikologi; (3) perguruan tinggi; dan (4) alumni. Dengan program kerjasama \\
& tersebut siswa mengakui banyak terbantu dalam memahami-mengembangkan \\
& potensinya, mengatasi hambatannya, dan melakukan perencanaan individual.
\end{tabular}

CEdu Consilium: Jurnal Bimbingan dan Konseling Pendidikan Islam Institut Agama Islam Negeri Madura, Indonesia

\section{PENDAHULUAN}

Setiap Guru Bimbingan dan Konseling di satuan pendidikan formal memiliki wewenang untuk merencanakan program kemudian merealisasikan perencanaan program tersebut secara bertanggung jawab. Pelaksanaan program dapat terlaksana secara efektif 
dengan pengelolaan yang benar sesuai dengan sistem manajemen yang dibentuk oleh tim pelaksana layanan BK di masing-masing sekolah. Guru BK disyaratkan melakukan need assessment pada seluruh peserta didik sebagai konseli dengan berbagai instrumen yang tepat sehingga perencanaan program BK terencana sesuai kebutuhan dan kondisi peserta didik. Dalam BK komprehensif perencanaan program BK ditujukan untuk memaksimalkan seluruh aspek perkembangan siswa secara harmoni dan seimbang (Burnham \& Jackson, 2000: 44; Studer \& Diambra, 2010: 129) melalui pemahaman diri, pengembangan potensi, kemampuan beradaptasi, dan merencanakan masa depan.

Komponen dukungan sistem memiliki tujuan memberikan dukungan pada Guru BK dalam memperlancar pelaksanaan program BK dimana salah satu fokus pengembangannya adalah menyelenggarakan program kerjasama (Permendikbud, 2014: 12). Keterlaksanaan program yang baik sebagai proses pencapain tujuan program BK tidak seluruhnya dapat dilakukan hanya oleh tenaga BK, karena itu program BK merupakan tanggung jawab bersama, dilaksanakan oleh seluruh tenaga BK, melalui program pengembangan yang berkelanjutan, dengan kegiatan kolaborasi serta pengembangan kerjasama (Scott, Alter, Rosenberg, \& Borgmeier, 2010: 530) dengan tenaga pendidikan yang ada di sekolah dan pihak-pihak di luar sekolah yang selaras dengan tujuan-tujuan program BK.

Kegiatan kolaborasi di dalam lingkungan sekolah dapat dilakukan bersama kepala sekolah, guru, dan wali kelas. Sementara dengan pihak di luar lingkungan sekolah dapat dilakukan dengan berbagai pihak dan lembaga formal yang dapat memberikan sumbangsih penting bagi perkembangan siswa. Kolaborasi dengan pihak-pihak tersebut merupakan sebuah keharusan karena optimalnya potensi yang siswa miliki merupakan hasil yang diharapkan oleh masing-masing stakeholder melalui peran dan tanggung jawabnya. Bahkan dengan dengan model kolaborasi antara guru dan konselor dapat meningkatkan keterampilan komunikasi siswa cerdas istimewa yang menerima alokasi waktu belajar lebih panjang setiap harinya dibandingkan siswa reguler (Hastiani, dkk., 2014: 5). Dan semenjak tahun 1999 konsultasi merupakan bagian penting dari tugas konselor sekolah, di satu waktu konselor sebagai konsulti dan pada kesempatan lain konselor sebagai konsultan. Konsultasi merupakan upaya untuk mengatasi berbagai tantangan dan kesulitan yang dihadapi siswa (Sciarra, 2004: $53)$.

Salah satu peran penting konselor adalah menjadi anggota tim, a professional helper (Gibson \& Mitchell, 2011: 113). Profesi-profesi yang biasanya ada dalam tim ini adalah psikolog sekolah/ pendidikan, pekerja sosial, tenaga kesehatan, psikiater, spesialis tunarungu, 
dan tunawicara. Dengan adanya profesi penolong lainnya maka Guru BK perlu mengetahui latar pendidikan dari profesi-profesi itu agar dapat menggunakan jasa mereka sesuai kebutuhan dan tujuan, dapat berkomunikasi secara efektif dengan mereka, dan bekerjasama mengatasi permasalahan yang menjadi kepedulian bersama (Gladding, 2012: 45). Namun di Indomesia tim seperti ini masih jarang ditemukan. Umumnya Guru BK merupakan tim independen sekolah yang dapat membuat program kerjasama untuk mengembangkan kegiatan layanan BK. Kesadaran akan profesionalisme yang harus direalisasikan menjadi dasar bagi Guru BK untuk bekerjasama dengan profesi lainnya yang dipandang memiliki legalitas dan akurasi bantuan sehingga siswa mendapatkan pelayanan terbaik dari program BK yang ada. Selain itu kegiatan kerjasama merupakan fungsi dasar yang dapat membangun dan mempertahankan hubungan-gubungan profesional yang positif.

Perencanaan individual merupakan aktivitas BK yang banyak dibahas dan dikembangkan dalam tahun-tahun ini, di mana implementasinya dapat dilakukan dengan berbagai cara, tujuan utamanya adalah membantu seluruh siswa agar memiliki kecakapan serta kesiapan untuk menjadi apa yang mereka inginkan di masa depan (Axinte, 2014: 259). Aktivitas dalam pencapaian hal tersebut ialah dengan membantu siswa memahami perkembangan karir, akademik, dan pribadi-sosial. Guru BK secara periodik memantau perkembangan tersebut. Guru BK perlu melakukan kolaborasi dengan orang tua dan menggunakan berbagai strategi seperti bekerjasama dengan penasehat ahli perkembangan, melakukan kegiatan penempatan dan penyaluran, berkonsultasi dengan pendidik lainnya, dan dengan lembaga atau institusi yang dipandang dapat menfasilitasi kebutuhan siswa terkait dengan pengembangan-analisa-evaluasi-realisasi dari tujuan dan perencanaan pekerjaan dan pekerjaan siswa (Gysber \& Henderson, 2001: 250-251; Burkard, dkk, 2012: 139).

Implementasi program BK seluruhnya dapat berjalan baik apabila terjalin program kerjasama, kolaborasi, dan konsultasi dengan pihak-pihak terkait, seluruh pihak perlu memiliki pandangan sama mengenai pelayanan yang berpihak pada kepentingan siswa. Setiap pihak memiliki andil yang sama pentingnya dan perlu saling mendukung walaupun tidak terbentuk tim dengan keanggotaan yang sama di setiap tahun berjalannya program BK, namun setiap pihak yang bersedia mendukung Guru BK perlu memiliki komitmen untuk memberikan pelayanan terbaik agar siswa mampu menjadi dirinya sendiri. Atas dasar itulah fokus dari penelitian ini adalah pola kerjasama antara Guru BK dengan profesional lain dan dibatasi hubungan kerjasama dengan profesional dan institusi atau lembaga di luar sekolah, di mana setiap bentuk kerjasama memiliki tujuan yang berbeda dan bentuk kegiatan yang 
beragam. Fokus kedua adalah pada bagaimana program kerjasama tersebut dapat membantu siswa memahami diri dan melakukan perencanaan individual. Maka tujuan dari penelitian ini adalah: (1) mengorganisasikan bentuk kerjasama antara Guru BK dengan profesional lainnya; dan (2) menelaah manfaat yang siswa peroleh dari program kerjasama bimbingan dan konseling.

\section{METODE}

Penulis menggunakan jenis penelitian deskriptif kualitatif dimana data dikumpulkan dengan metode wawancara, observasi, dan dokumentasi. Pertanyaan-pertanyaan wawancara diajukan kepada Guru BK MAN 1 Yogyakarta, psikolog, motivator, alumni, dan siswa. Pemilihan responden penelitian menggunakan prinsip purposive sampling. Pengamatan observasi pada kegiatan bimbingan klasikal, kegiatan pelatihan, dan acara career day. Kemudian metode dokumentasi dengan mengamati hasil psikotes milik 10 siswa yang bersedia menunjukkan hasil tesnya pada penulis, program BK tahun 2020, MoU Kerjasama antara sekolah (dalam hal ini terkait program BK) dan lembaga penyelenggara psikotes, instrument tes dan non-tes.

\section{HASIL}

BK MAN 1 Yogyakarta memiliki beberapa program kerjasama untuk membantu siswa memaksimalkan potensinya, di mana program kerjasama ini selalu dijalin setiap tahun oleh guru BK dengan profesional lainnya, yaitu dengan lembaga psikologi, motivator, perguruan tinggi, dan alumni madrasah. Kerjasama berkelanjutan ini memiliki pola-pola berupa kegiatan dan tujuan yang ingin dicapai dari setiap kegiatannya. Pola-pola tersebut dapat penulis lihat karena setiap tahun terdapat rangkaian kegiatan yang sama dengan tujuan yang secara umum juga sama seperti tahun-tahun sebelumnya. Program kerjasama profesional tersebut juga selalu dijalin karena setiap siswa baru juga siswa-siswa yang telah lebih jauh beradaptasi dengan berbagai kegiatan di madrasah selalu menghadapi situasi yang serupa dengan pengalaman siswa-siswa pendahulu. Hal ini berkaitan dengan perkembangan siswa dan tantangan-tantangan umum yang cenderung selalu siswa hadapi, maka melalui bekerjasama dengan pihak-pihak profesional tersebut Guru BK secara bertanggungjawab memberikan pelayanan yang tepat dan program-program BK yang sesuai dengan kebutuhan siswa. 


\section{Penyelenggaraan Psikotes}

Guru BK MAN 1 Yogyakarta selalu menjalin kerja sama dengan sebuah lembaga psikologi, kerjasama dengan lembaga psikologi ini bertujuan untuk mengetahui potensipotensi siswa. Guru BK membutuhkan tenaga profesional lain dalam melakukan need assessment karena tidak memiliki legalitas untuk memberikan tes terstandar, maka dalam kegiatan assessment Guru BK hanya melakukan asesmen non-tes berupa observasi, wawancara, dan membuat instrumen daftar masalah kemudian menganalisanya secara manual. Dalam prakteknya Guru BK menggabungkan hasil dari asesmen tes dan non-tes untuk menyusun program BK, mengambil tindakan yang dibutuhkan siswa, dan membantu siswa melakukan perencanaan individual. Setiap siswa mengikuti psikotes yang diselenggarakan di madrasah sebanyak dua kali, pertama saat menjadi siswa baru di kelas X dan kedua setelah menjadi siswa kelas XII sebelum pelaksanaan UN.

\section{Pelaksanaan Achievement Motivation Training (AMT)}

AMT merupakan program tahunan di MAN 1 Yogyakarta, merupakan salah satu bentuk pelatihan motivasi pencapaian prestasi yang secara massal (gabungan siswa dari semua kelas) di madrasah. AMT dipercayakan kepada motivator yang berbeda setiap tahunnya, dengan menghadirkan motivator dalam pelatihan ini siswa terbantu untuk semakin memahami kelebihan dirinya, memiliki optimisme untuk mencapai prestasi-prestasi di sekolah dan di luar sekolah, dan membentuk motivasi pengembangan diri dalam berbagai aktivitas akademik dan non-akademik yang siswa minati.

\section{Bimbingan Karir dan Expo Karir}

Bimbingan karir di MAN 1 Yogyakarta diberikan oleh Guru BK kepada siswa sejak siswa berada di kelas $\mathrm{X}$ dan kemudian diselengarakan lebih spesifik dan intensif pada siswa kelas XII yang akan melanjutkan studi ke perguruan tinggi (PT) setelah lulus dari madrasah. Bimbingan karir yang Guru BK berikan pada kelas XII khusus mengenai pengenalan perguruan tinggi, klasifikasi bidang studi yang ada di perguruan tinggi, informasi mengenai persiapan dan cara mendaftar di perguruan tinggi, menyiapkan brosur-brosur berbagai perguruan tinggi agar dibaca oleh siswa, dan membantu siswa memantapkan pemilihan jurusan. Lebih lanjut agar siswa mendapatkan informasi lebih akurat mengenai berbagai jurusan dan kegiatan yang ada di perguruan tinggi, maka Guru BK bekerjasama dengan beberapa PT swasta dan negeri yang ada di wilayah Yogyakarta untuk memberi wawasan 
mengenai aktivitas dan proses belajar di perguruan tinggi masing-masing yang akan siswa pilih. Kerjasama ini berjalan efektif setiap tahunnya, dengan mendatangkan narasumber dari PT secara langsung merupakan sebuah kesempatan bagi siswa untuk memperoleh informasi lebih banyak tentang perguruan tinggi yang ingin dituju.

Dua minggu setelah bimbingan karier dari narasumber PT, Guru BK mengadakan hari karir (career day) di madrasah yang sasarannya adalah seluruh siswa di madrasah, maka seluruh siswa yang ingin mengetahui informasi seputar perguruan tinggi dapat menghadiri acara tersebut. Pekan karir ini menjadi kesempatan berharga terutama bagi siswa kelas XII untuk mengumpulkan banyak informasi mengenai rencana studi lanjut dan pemilihan kampus sehingga siswa memiliki pertimbangan yang makin matang dalam menyeleksi pilihan-pilihan hingga akhirnya mampu memutuskan untuk mendaftar di satu atau beberapa alternatif PT.

PT yang ada di acara hari karir merupakan PT yang mendapatkan undangan dari sekolah, setiap PT diwakili oleh 2-3 orang yang menempati biliknya masing-masing. Di setiap bilik terdapat brosur berisi informasi umum PT sementara siswa dapat bertanya pada pihak perwakilan PT secara terbuka mengenai apa pun yang ingin siswa ketahui dari PT yang siswa minati. Penyajian informasi berbentuk kegiatan terbuka seperti career day ini telah membentuk kemandirian siswa dalam pencarian dan penyaringan informasi yang ingin diperoleh dengan berkomunikasi langsung dengan pihak perwakilan PT, mendapatkan brosur informasi PT, dan melihat berbagai PT yang hadir sebagai alternatif pilihan. Informasi karir menjadi lebih komprehensif dan menarik dimana siswa memperolehnya langsung dari PT itu sendiri.

\section{Kegiatan Alumni Berbagi}

Alumni MAN 1 Yogyakarta tercatat melanjutkan studi baik di dalam negeri maupun luar negeri seperti Mesir, Jerman, dan Australia. Guru BK turut mengundang alumni tertentu untuk berbagai pengalaman aktivitas belajar di kampus, memberi motivasi pada siswa agar memiliki kemauan belajar sepanjang hayat, menumbuhkan optimisme para siswa yang ingin mendaftar ke kampus tujuan, menceritakan pengalaman kerja paruh waktu di sela-sela waktu perkuliahan, memberi gambaran interaksi antar mahasiswa terutama jika studi lanjut di luar negeri, memberi saran bagaimana beradaptasi dengan lingkungan dan orang-orang asing atau baru dikenal, menginformasikan kegiatan-kegiatan belajar yang bisa dilakukan secara mandiri di luar kelas, berbagi pengalaman mengenai pengembangan diri, dan tempat-tempat yang dapat dikunjungi saat libur kuliah. Kepada siswa yang ingin melanjutkan studi ke luar 
negeri, alumni juga membagi tips bagaimana agar lolos dan diterima oleh PT luar negeri yang ingin siswa tuju.

\section{PEMBAHASAN}

\section{Tujuan dan Manfaat Psikotes}

Psikotes yang diberikan pada kelas $\mathrm{X}$ bertujuan untuk memeroleh data mengenai potensi-potensi siswa berupa taraf kecerdasan intelektual, bakat, minat, dan kepribadian siswa; membantu siswa mengetahui potensi-potensi diri yang bisa dikembangkan selama menjadi siswa di madrasah; memberikan pemahaman yang utuh kepada siswa mengenai dirinya berupa kelemahan dan kelebihan; memantapkan pilihan-pilihan siswa berupa perencanaan lebih lanjut mengenai studinya; sebagai landasan bagi siswa dalam memilih kegiatan ekstra di madrasah; dan sebagai acuan bagi konselor dalam pelayanan penyaluran dan penempatan.

Jadi dengan hasil analisa psikotes Guru BK dapat membantu siswa dalam memilih berbagai kegiatan yang ingin siswa ikuti di sekolah, menyalurkan siswa pada pencapaian prestasi non-akademik seperti mengikuti lomba, mempermudah pembagian kelompok belajar, dan sebagai acuan siswa sebelum memilih jurusan di madrasah dan juga menjadi argumen logis bagi Guru BK saat mengarahkan siswa yang memilih jurusan yang tidak sesuai dengan kemampuannya, terlebih jika orang tua siswa tidak menyetujui pilihan siswa maka data hasil psikotes juga sajian data lain seperti hasil prestasi akademik dapat menjadi penjelasan bagi wali siswa mengenai pilihan siswa, potensi yang dimiliki, dan harapan-harapan orang tua.

Hasil tes kepribadian juga membantu siswa dalam memahami dirinya, kepribadian siswa ini bisa menjadi kelebihan dan juga kelemahan bagi siswa, seperti siswa dengan kepribadian introvert yang memiliki kelebihan berupa kemandirian dalam menuntaskan berbagai tugas namun kesulitan dalam melakukan komunikasi interpersonal dan lebih lama melakukan adaptasi dengan lingkungan baru.

Hasil tes ini menjadi bahan materi dalam pelayanan BK, di mana materi tersebut membantu siswa untuk lebih memahami siapa dirinya dan bagaimana melakukan adaptasi dengan kondisi yang siswa miliki. Guru BK juga dapat menunjukkan prediksi-prediksi yang akan siswa dapatkan jika dapat mengarahkan diri secara efektif dan kendala apa yang bisa siswa peroleh jika siswa tidak mampu menerima dirinya. Dengan mengetahui tipe kepribadian siswa Guru BK dapat semakin mematangkan pelaksanaan layanan BK seperti 
teknik dan strategi konseling yang sesuai dengan kepribadian siswa sehingga sesi-sesi konseling semakin efektif.

Sementara psikotes bagi kelas XII untuk mengetahui perkembangan potensi dan kondisi psikologis lainnya pada diri siswa serta lebih ditekankan pada pemilihan jurusan di perguruan tinggi, karena itu dalam hasil analisa psikotes juga tertulis saran berupa jurusan yang bisa siswa pilih yang sesuai dengan potensi yang dimilikinya, di mana potensi tersebut didapatkan dari tipe kepribadian, bakat, minat, sikap, taraf kecerdasan intelektual, dan kecenderungan etos kerja siswa. Psikotes yang diberikan pada kelas XII merupakan psikotes kedua bagi siswa, pada beberapa siswa terdapat perubahan hasil seperti taraf kecerdasan intelektual yang menurun dan perubahan minat.

Setelah psikolog membagikan hasil psikotes pada siswa, psikolog yang bertugas menjelaskan cara memahami hasil tes tersebut, termasuk memberi penjelasan tentang perubahan hasil psikotes atara pertama saat kelas $\mathrm{X}$ dan kedua, dan membagikan pengalaman beberapa mahasiswa yang sukses di perguruan tinggi, memberi gambaran mengenai berbagai jurusan yang ada di perguruan tinggi, dan memberi arahan mengenai cara menentukan jurusan agar benar-benar sesuai dengan potensi masing-masing siswa. Selama bimbingan klassikal tersebut terjadi dialog dua arah, psikolog mampu mengontrol kondisi kelas dan menanggapi setiap pertanyaan siswa.

Pengisian bimbingan oleh psikolog terlaksana selama 3 hari dan di luar kelas pun siswa masih diberi kesempatan untuk menanyakan hal-hal yang belum mereka pahami secara jelas, proses konsultasi pemilihan jurusan terus berlangsung dengan Guru BK. Proses kerjasama dengan psikolog berlangsung mulai dari pengisian instrumen tes oleh siswa, pembagian hasil tes sekaligus pelaksanaan bimbingan klassikal di setiap kelas, dan proses konsultasi dengan Guru BK secara berkelanjutan.

\section{Respon Siswa Terhadap AMT}

Motivator yang diundang merupakan seorang profesional dengan sejumlah pengalaman dalam memberi pelatihan. Sebelum acara AMT dilaksanakan, profil mengenai motivator diinformasikan pada siswa sehingga siswa dapat mengetahui latar belakang dan prestasi dari motivator tersebut. Hal ini dilakukan untuk membangun minat siswa terhadap acara AMT, membentuk rasa kepercayaan siswa pada motivator yang diundang sehingga siswa meyakini kemampuan yang dimiliki motivator, sehingga motivator merupakan sosok yang dapat dipercaya dan dapat membagikan energi positif dalam pengembangan diri. 
Kepercayaan siswa terhadap motivator yang berpengalaman, membuat siswa semakin antusias untuk menyimak materi yang disampaikan dan siswa menjadi aktif bertanya tentang cara mengenali potensi diri, mengelola kelemahan, pengaturan kegiatan, menjaga konsistensi motivasi, cara meraih prestasi, dan hal-hal lain yang berhubungan dengan motivasi berprestasi.

\section{Informasi Karir Untuk Menentukan Kampus Tujuan}

Siswa perlu mendapatkan informasi yang tepat mengenai jurusan yang diminati, selain kesesuaian antara potensi yang dimiliki dan jurusan pilihannya, melalui narasumber dari PT siswa akan memiliki alasan lebih rasional mengapa siswa lebih memilih jurusan tertentu di satu PT dibandingkan dengan PT lainnya, hal seperti ini seringkali tidak mudah bagi siswa karena siswa tidak hanya cukup mengetahui nilai akreditasi saja namun perlu mendapatkan gambaran utuh mengenai kegiatan belajar yang akan dialaminya setelah menjadi mahasiswa seperti mata kuliah apa saja yang akan dipelajari, bagaimana kondisi sarana dan prasarana yang mendukung aktivitas belajar, keterampilan para pengajar, kesempatan-kesempatan seperti beasiswa dan kegiatan-kegiatan kampus yang menunjang pengembangan dan keterampilan, apa yang bisa dilakukan dan siapa yang bisa siswa hubungi jika mendapatkan sutau hambatan, dan profil-profil alumni dari PT tujuan siswa yang sering kali menjadi acuan siswa untuk menilai kualitas jurusan serta PT tujuannya.

Career day merupakan aktivitas yang berbentuk large group sessions, acara tersebut serupa dengan educationall collegel vocational day. Pelaksanaan hari karir yang telah direncanakan secara matang ini memang merupakan tugas serta tanggung jawab Guru BK sebagai organisator acara, namun dengan kehadiran berbagai PT adalah bentuk dukungan dan kemauan bekerjasama merupakan faktor yang juga dibutuhkan untuk kesuksesan program BK.

\section{Pengalaman Alumni Sebagai Wawasan Karir}

Mendatangkan alumni ke madrasah untuk berbagai pengalaman menempuh studi lanjut di PT bertujuan memberi contoh dan wawasan pada siswa agar dapat mencontoh keberhasilan yang dicapai para seniornya. Berbagai kegiatan yang dilakukan alumni di kampusnya bisa menginspirasi dan dijadikan informasi awal yang bermanfaat bagi para siswa. Bertemu langsung dengan mahasiswa yang memiliki cukup pengalaman selama kuliah, memiliki cukup informasi untuk dibagikan, dan terlebih alumni tersebut menggapai 
prestasi di bidangnya melalui keterampilan-keterampilan yang ia kembangkan memiliki nilai lebih berupa terbentuknya ikatan emosional antara senior dan junior di madrasah. Kemauan alumni untuk berbagi menjadi media komunikasi interaktif antara alumni dan siswa yang ingin mengetahui lebih banyak hal mengenai dunia yang tak lama lagi akan siswa jalani.

Berbagai hal yang alumni sampaikan, ditambah foto-foto dari kegiatannya di kampus tempat belajar menumbuhkan semangat dan optimisme para siswa, yakni tumbuhnya keyakinan bahwa para siswa juga dapat melakukan yang terbaik selama ada kemauan dan terus berusaha mencapai impian dan cita-cita. Di sisi lain, alumni juga menjadi motivator bagi para siswa dengan berbagi pengalaman mewujudkan keinginan selama belajar di kampus, alumni dapat menjadi teladan bagi siswa bahwa suatu capaian akan maksimal saat dilakukan dengan tekun, adanya konsistensi belajar, dan selalu melakukan kegiatan positif di dalam maupun luar kampus.

Siswa pada akhirnya mendapatkan serangkaian pemahaman bahwa saat mereka menjadi mahasiswa maka kegiatan belajar bukan sebatas yang berhubungan langsung dengan materi perkuliahan dan tidak hanya dapat dilakukan di dalam kelas dengan para dosen, namun pembelajaran dan pengembangan diri juga bisa dilakukan secara mandiri dan berkelompok dengan teman-teman di dalam kelas maupun di luar kelas.

\section{Keunggulan Program Kerjasama dalam Pelaksanaan Program BK dan Manfaatnya Bagi Pengembangan Potensi Siswa}

Pertama, kegiatan asesmen kebutuhan siswa dengan tes terstandar sangat dirasakan manfaatnya oleh siswa, dengan mengetahui kondisi pribadi berdasarkan hasil psikotes siswa menjadi lebih mengetahui tentang dirinya; sejak di kelas X siswa sudah mengetahui potensipotensi yang bisa dikembangkan, jika sebelumnya apa yang menjadi bakat dan minatnya masih sebatas dugaan atau pemikiran pribadi maka setelah membaca hasil tes siswa memperoleh kepastian mengenai jenis bakat dan minatnya, hal ini berdampak positif bagi siswa saat memilih kegiatan ekstra sekolah dan saat penjurusan di madrasah. Memang tidak semua siswa dapat langsung memahami bagaimana cara merealisasikan diri sesuai dengan potensi dan kelemahan yang siswa miliki dalam dirinya, namun dengan program bimbingan yang berkelanjutan oleh Guru BK secara bertahap membantu siswa untuk semakin menerima dan memahami kondisi pribadinya seperti kecenderungan kemampuan akademik yang bisa optimal jika siswa merubah pilihan jurusan sesuai potensinya. Siswa menyampaikan bahwa apa yang Guru BK arahkan pada siswa memang benar-benar objektif sesuai data pribadi 
siswa, jadi saat melakukan proses bimbingan maupun konseling siswa mudah memahami informasi dari Guru BK karena sudah sesuai dengan hasil psikotes yang menurut siswa sesuai dengan pemikiran pribadinya.

Kedua, pemberian informasi dan bimbingan dari psikolog saat siswa kelas XII. Hasil psikotes kedua membantu siswa memahami mengapa ada perubahan hasil pada bagian tertentu, menurut siswa analisa yang psikolog sampaikan sesuai dengan kenyataan yang siswa jalani, seperti rasa malas siswa untuk belajar yang memengaruhi penurunan taraf kecedasan intelektual siswa. Begitu juga dengan rekomendasi jurusan yang tertera dalam hasil psikotes siswa akui sudah sesuai dengan bakat beserta minatnya. Selain dari keabsahan alat tes, rasa kepercayaan siswa terhadap hasil psikotesnya menunjukkan bahwa hasil psikotes memiliki nilai akurasi tinggi.

Ketiga kegiatan AMT, siswa berpendapat bahwa motivator memang orang yang handal dan memiliki cukup pengalaman sehingga kegiatan pelatihan AMT sangat menyenangkan bagi siswa karena di dalam kegiatan tersebut siswa tidak hanya menerima sajian materi namun juga terdapat kegiatan seperti brain storming. Kegiatan kreatif seperti brain storming membuat siswa tidak jenuh dalam memahami substansi dari kegiatan pelatihan. Dengan demikian pemilihan motivator pengisi kegiatan AMT tidak hanya berkualitas menurut pandangan Guru BK, namun kualitas motivator juga terbukti berdasarkan pendapat siswa yang menyampaikan bahwa kegiatan AMT dapat menumbuhkan optimisme siswa untuk merealisasikan perencanaan masa depan.

Keempat, career day yang diperuntukkan bagi seluruh siswa yang berminat mengetahui lebih banyak informasi mengenai PT mendapatkan respon positif dari siswa. Bagi siswa kelas $\mathrm{X}$ acara tersebut menarik karena siswa mendapatkan informasi mengenai PT sejak dini sehingga siswa memiliki gambaran mengenai pemilihan penjurusan yang kemungkinan besar akan mereka lakukan saat naik kelas XII. Pada kelas XI wawasan mengenai PT memang sudah mulai diberikan namun belum begitu intensif, maka dengan menghadiri acara career day siswa mulai bersiap melakukan perencanaan pilihan karir. Terutama bagi kelas XII dengan adanya acara ini siswa memeroleh kesempatan untuk mendapatkan berbagai informasi yang dibutuhkan, siswa mendapatkan akses yang mudah untuk mencari informasi dengan dihadirkannya sejumlah PT sehingga dapat menjawab kebutuhan siswa. Career day merupakan program kerjasama yang hanya diadakan sekali dalam satu tahun namun jangkauannya adalah seluruh siswa di mana orientasi dari madrasah bertujuan menambah wawasan dan menumbuhkan motivasi untuk studi lanjut. Pada akhirnya 
siswa memiliki kemampuan memilih jurusan berserta PT sesuai dengan kemampuana kademik dan pertimbangan lainnya seperti dukungan orang tua, kemampuan finansial, kemampuan beradaptasi dengan kurikulum PT, peluang dan kesempatan mengaktualisasikan diri dengan sarana serta prasarana jurusan atau PT, atau keinginan studi sambil lalu bekerja paruh waktu.

Kelima, hal-hal yang dibagikan oleh alumni pada para siswa seperti suasana belajar yang berbeda antara di PT dan di sekolah, perlunya kemandirian untuk mencapai prestasi di samping adanya interaksi kelompok dan dukungan keluarga, berbagi cara pemecahan masalah yang menganggu aktivitas belajar, cara memaksimalkan berbagai kesempatan yang ada di PT, dan pengalaman lainnya dinilai bermanfaat sebagai informasi yang membuka wawasan karir siswa, dapat membantu siswa dalam persiapan peralihan tempat belajar, dan membentuk kematangan berpikir siswa. Kerjasama pemberian motivasi, informasi, dan wawasan umum mengenai aktivitas di PT dengan alumni selalu dilakukan karena para siswa selalu memiliki antusiasme untuk mendengarkan apa yang telah dijalani dan dicapai oleh seniornya. Kerjasama dengan alumni juga dapat dikatakan sebagai kerjasama profesional karena alumni yang diundang adalah alumni yang dinilai dapat memotivasi dan membagikan nilai-nilai positif dengan melihat pencapaian akademik dan non-akademik yang diraih oleh alumni selama menempuh pendidikan di perguruan tingginya.

\section{SIMPULAN}

Kerjasama profesional bimbingan dan konseling terorganisir sesuai dengan perencanaan serta pelaksanaan program tahunan BK, kerjasama dilakukan atas dasar lima hal yaitu: (a) memaksimalkan kerja kolaboratif; (b) solusi bagi keterbatasan Guru BK; (3) komitmen mengutamakan profesionalisme; (d) memenuhi kebutuhan siswa yang semakin beragam dan kompleks; dan (e) membangun rasa kepercayaan dan perilaku saling bertanggung jawab antara pihak BK dengan pihak profesional lainnya. Kerjasama dengan lembaga psikologi dilakukan karena Guru BK tidak memiliki legalitas menyelenggarakan tes terstandar, bertujuan untuk mengetahui kebutuhan siswa, dan membantu siswa dalam pemahaman diri dan perencanaan masa depan. Motivator dipercaya memberikan pelatihan AMT agar siswa memiliki motivasi mengembangkan diri, optimisme menggapai prestasi, dan memiliki wawasan mengenai cara mengelola diri. Sejumlah PT di wilayah Yogyakarta diundang untuk memberi bimbingan karir dan menghadiri acara career day yang dalam pelaksanaannya siswa mendapatkan cukup informasi mengenai jurusan dan PT tujuan 
sehingga siswa memiliki kemampuan membuat keputusan studi lanjut dengan pilihan jurusan sesuai potensi di PT yang siswa pilih secara sadar, mandiri, dan bertanggungjawab. Kemudian kerjasama dengan alumni fokus kepada berbagai pengalaman di mana siswa bisa memeroleh pembelajaran, wawasan, dan informasi seputar kegiatan yang bermanfaat di PT dalam negeri maupun luar negeri.

Keempat model program kerjasama memberikan manfaat tersendiri bagi pihak siswa, siswa telah mendapatkan manfaat sesuai dengan tujuan masing-masing kegiatan kerjsama profesional tersebut. Dengan psikotes siswa dapat mengenali dirinya, dapat mengembangkan potensi sesuai kemampuan yang dimilikinya, dapat melakukan perencanaan individual jangka pendek dan jangka panjang berupa pemilihan kegiatan di sekolah, di luar sekolah, serta pemilihan studi lanjut, dan memiliki kemampuan mengatasi hambatan-hambatan pribadi, sosial, belajar, dan karir. Career day berhasil memberikan informasi karir berupa informasi jurusan dan perguruan tinggi yang siswa inginkan dari sumber yang terpercaya. Sementara motivator dapat membentuk optimisme siswa untuk mewujudkan prestasi sesuai kemampuan masing-masing siswa. Sebagai pelengkap yang tak kalah urgen, kehadiran alumni menambah semangat siswa untuk bersungguh-sungguh mempersiapkan studi lanjutnya sebaik mungkin.

\section{DAFTAR RUJUKAN}

Axinte, Roxana. (2014). The school counselor: Competencies in a constructivist model of counseling for career development. Procedia - Social and Behavioral Sciences, 142, 255-259. doi:10.1016/j.sbspro.2014.08.290.

Burkrad, A. W., Gillen, M., Martinez, M. J., \& Skytte, S. L. (2012). Implementation challenges and training needs for comprehensive school counseling programs in wisconsins high schools. Professional School Counseling, 16 (2), 136-145.

Burnham, J., \& Jackson, C. (2000). School counselor roles: Discrepancies between actual practice and existing models. Professional School Counseling, 4, 41-49.

Gibson, R. L. \& Mitchell, M. H. (2010). Bimbingan dan konseling. Yogyakarta: Pustaka Pelajar.

Gladding, Samuel T. (2012). Konseling profesi yang menyeluruh. Jakarta: PT. Indeks.

Gysbers, Norma C. \& Henderson, Patricia. (2001). Comprehensive guidance and counseling program: a rich history and a bright future. Professional School and Counseling, 4 (4), 246-255.

Hastiani, dkk. (2014). Guidance and counseling teacher and subject teacher collaboration model increasing the interpersonal communication skill of special intelligent students. Jurnal Bimbingan Konseling, 3 (1), 1-8.

Sciarra, Daniel T. (2004). School counseling; foundations and contemporary issues. USA: Thompson Learning, Inch.

Scott, T., Alter, P., Rosenberg, M., \& Borgmeier, C. (2010). Decision-making in secondary and tertiary interventions of school-wide systems of positive behavior support. Education \& Treatment of Children, 33, 513-535. 
Studer, J. R., \& Diambra, J. F. (2010). The delivery system component. In J. Studer \& J. Diambra (Eds.), A guide to practicum and internship for school counselors-in-training (pp. 119-132). New York: Routledge/Taylor \& Francis. 